\title{
Mantle Cell Lymphoma Payudara, suatu kasus jarang
}

\author{
Valencia ${ }^{1}$, Aswiyanti Asri ${ }^{1}$, Hera Novianti ${ }^{3}$
}

\begin{abstract}
Abstrak
Mantle cell lymphoma (MCL) adalah neoplasma sel $\beta$-matur yang biasanya terdiri dari sel limfoid monomorf berukuran kecil hingga sedang dengan kontur inti ireguler, pada > 95\% kasus, terdapat translokasi Cyclin D1 (CCND1). Limfoma payudara merupakan suatu kasus yang jarang. Dilaporkan seorang pasien perempuan usia 50 tahun yang datang dengan keluhan massa di payudara kanan sejak satu tahun yang semakin bertambah besar. Pemeriksaan fisik didapatkan tumor ukuran 11x6x5 cm, konsistensi kenyal padat, terfiksir, dan berulkus. Tidak ditemukan Nipple discharge/bleeding dan pembesaran kelenjar getah bening tidak ditemukan. Pasien menjalani mastektomi. Pemeriksaan histopatologi tampak potongan jaringan payudara dengan stroma jaringan ikat dan jaringan lemak mengandung proliferasi sel-sel limfoid berukuran kecil, monoton dan tersebar difus di antara stroma. Sel-sel dengan inti pleomorfik, hiperkromatik, berlekuk, membran inti ireguler, di antaranya tampak beberapa sel plasma. Pemeriksaan imunohistokimia CD-20 dan Cyclin-D1 menunjukkan pulasan positif serta Ki-67 antara 30-40\%. Hasil pemeriksaan histopatologi dan imunohistokimia dapat disimpulkan diagnosis mantle cell lymphoma pada payudara.
\end{abstract}

Kata kunci: limfoma, MCL, payudara

\begin{abstract}
Mantle cell lymphoma (MCL) is a mature $\beta$-cell neoplasm consists of small to medium sized monomorphic lymphoid cells with irregular nuclear contours, Cyclin D1 (CCND1) translocation is present in> 95\% of cases. Breast lymphoma is a rare case. It has been reported a 50 years old female who had mass on the right breast since one year ago with increasing in size. Physical examination revealed tumor size $11 \times 6 \times 5 \mathrm{~cm}$, soft-solid consistency, fixed and ulceration was found. Nipple discharge / bleeding and lymph node enlargement were not found. The patient underwent a mastectomy. Histopathological examination showed pieces of breast tissue with stroma of connective tissue and fat tissue containing small, monotonous and diffuse proliferation of lymphoid cells between the stroma. Cells with pleomorphic nuclei, hyperchromatic, notched, irregular nuclear membranes, among which several plasma cells appear. Immunohistochemical examination CD 20 and Cyclin D1 showed positive staining and Ki-67 positive 30-40\%. The result from histopathological and immunohistochemical examinations, it was concluded that the diagnosis is mantle cell lymphoma in the breast.
\end{abstract}

Keywords: breast, lymphoma, MCL

Affiliasi penulis: ${ }^{1}$ Program Pendidikan Dokter Spesialis-1 Patologi Anatomik, Fakultas Kedokteran, Universitas Andalas, Padang, Indonesia. ${ }^{2}$ Bagian Patologi Anatomik, Fakultas Kedokteran, Universitas, Padang, Indonesia. ${ }^{3}$ RSUP Dr. M. Djamil Padang Korespondensi: valencia.rendri@gmail.com Telp: 085265638885

\section{PENDAHULUAN}

Limfoma payudara primer didefinisikan sebagai limfoma yang melibatkan satu atau kedua payudara dengan atau tanpa keterlibatan kelenjar getah bening aksila ipsilateral, tanpa adanya riwayat penyakit lain pada payudara serta tanpa adanya riwayat limfoma pada pasien sebelumnya. ${ }^{1,2}$ Limfoma primer sangat jarang mengenai payudara, hal ini mungkin dikaitkan dengan sangat jarangnya jaringan limfoid endogenous pada daerah ini. ${ }^{3}$

Limfoma payudara primer merupakan kasus yang jarang dengan subtipe terbanyak adalah limfoma non Hodgkin (LNH). Insiden LNH pada payudara sekitar $0,5 \%$ dari tumor ganas payudara, $1 \%$ dari semua $\mathrm{LNH}$ dan $2 \%$ dari limfoma ekstra nodal. ${ }^{4}$ 
Sebagian besar pasien dengan limfoma payudara primer adalah wanita paruh baya hingga lansia, usia rata-rata pada dekade keenam atau ketujuh. Sekitar $2 \%$ pasien limfoma payudara primer adalah laki-laki. Kadang-kadang penyakit dipengaruhi kehamilan atau menyusui pada pasien yang lebih muda. Jarang ada pasien memiliki riwayat karsinoma payudara sebelumnya. ${ }^{3}$

Sebagian besar pasien datang dengan keluhan massa payudara yang teraba dengan atau tanpa limfadenopati aksila ipsilateral. Lesi biasanya tidak menimbulkan rasa sakit. Beberapa pasien tidak menunjukkan gejala, dan pernah dilaporkan limfoma terdeteksi dengan mammografi. Limfoma terdeteksi lebih awal dengan mammografi rutin khususnya limfoma derajat rendah. Beberapa pasien memiliki riwayat penyakit autoimun, diabetes mellitus, atau mastitis. $^{4,5}$

\section{KASUS}

Perempuan berusia 50 tahun datang ke Poliklinik RSUP dr. M. Djamil Padang dengan keluhan utama benjolan di payudara kanan sejak satu tahun lalu yang semakin bertambah besar. Badan terasa letih dan lemah. Kulit tampak pucat. Berat badan menurun sekitar $5 \mathrm{~kg}$ dalam 2 bulan ini.

Pemeriksaan fisik regio mammae dekstra tampak massa dengan ulkus ukuran $11 \times 6 \times 5 \mathrm{~cm}$, konsistensi kenyal padat, terfiksir, terasa nyeri waktu ditekan. Berdasarkan hasil pemeriksaan fisik didiagnosis kerja sebagai tumor mammae dekstra suspek ganas.

Pasien menjalani mastektomi dekstra, jaringan dikirim ke laboratorium Patologi Anatomi RSUP dr. M.Djamil Padang. Makroskopik berupa massa putih kecoklatan berlemak, kenyal padat, batas tidak tegas.

Pada pemeriksaan mikroskopik tampak jaringan payudara dengan permukaan dilapisi epitel berlapis gepeng, di bawahnya tampak stroma mengandung proliferasi sel-sel limfoid berukuran kecil (1-2x ukuran limfosit) monoton dan tersebar difus di antara stroma. Sel-sel dengan inti pleomorfik, hiperkromatik, berlekuk, membrane inti irregular, diantaranya tampak beberapa sel plasma. Tampak juga kelenjar mammae normal yang dilapisi epitel kuboid (Gambar 1).

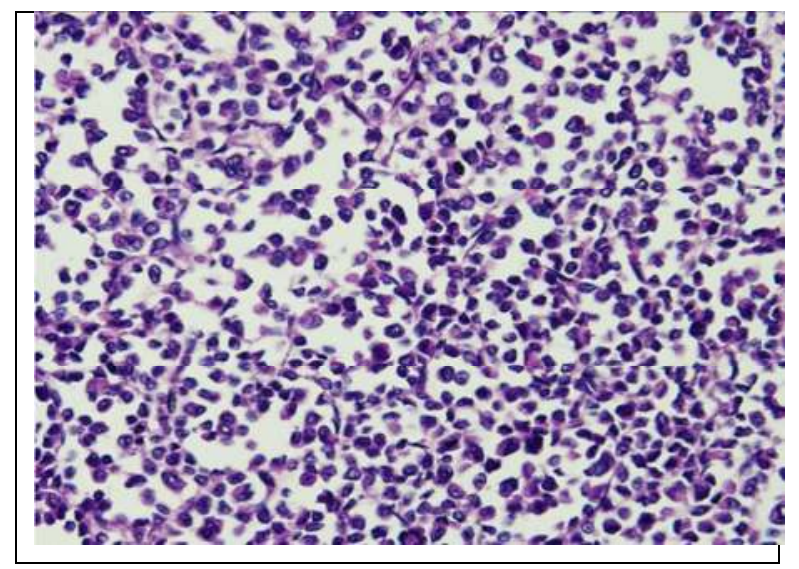

Gambar 1. Mikroskopik pola pertumbuhan LNH tipe sel kecil. Tampak proliferasi sel-sel limfoid berukuran kecil tersebar difus dengan inti pleomorfik, ada inti hiperkromatik, cleavage, membrane inti irregular.

Hasil pemeriksaan histopatologi ditegakkan diagnosis LNH tipe sel kecil suggestif Mantle cell lymphoma payudara. Konfirmasi diagnosis dilakukan pemeriksaan imunohistokimia CD 20, Cyclin D1, dan Ki-67. Pulasan imunohistokimia CD 20 tampak membran sel terwarnai positif pada sebagian besar sel tumor (gambar 2) dan Cyclin D1, tampak inti terwarnai pada sebagian besar sel tumor (gambar 3). Pada pulasan Ki-67 tampak inti terwarnai positif sedang-kuat pada sel tumor (indeks proliferasi 30\%-40\% (Gambar 4). Simpulan pemeriksaan imunohistokimia sesuai untuk mantle cell lymphoma pada payudara.

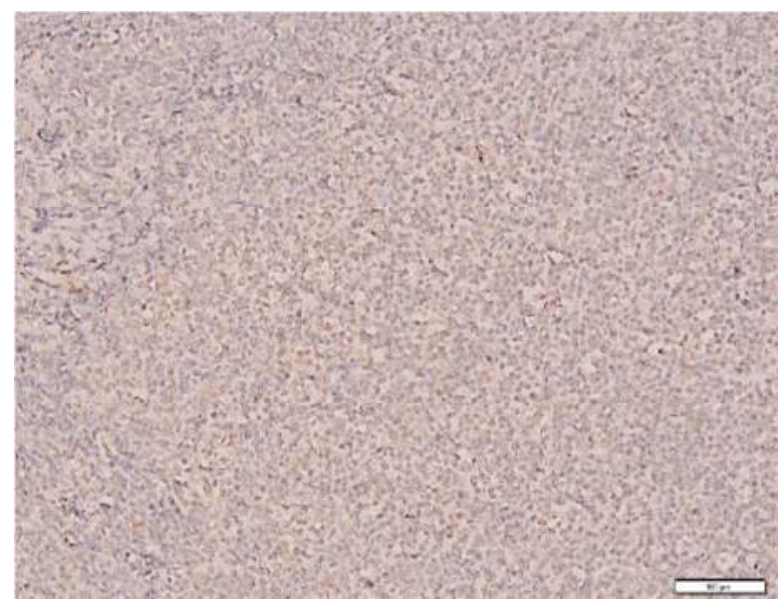

Gambar 2. Pewarnaan imunohistokimia CD20. Tampak membran sel terwarnai positif pada sebagian besar sel tumor. 


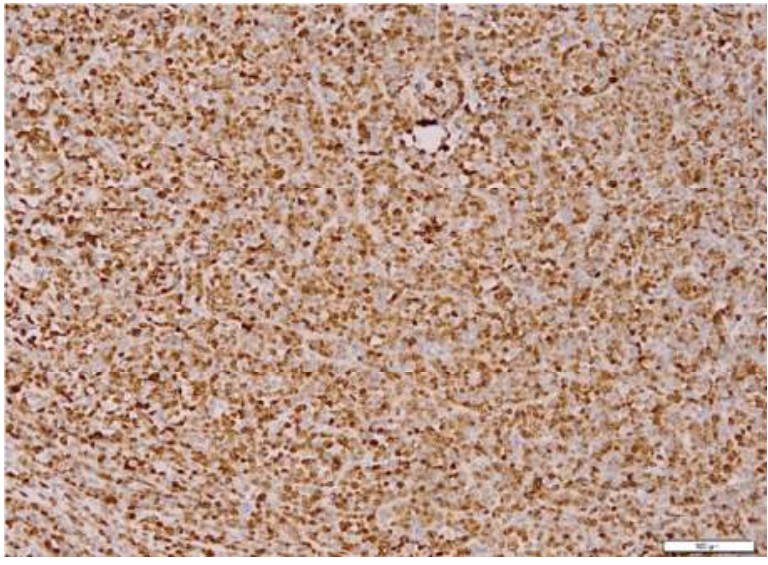

Gambar 3. Pewarnaan imunohistokimia Cyclin D1. Tampak inti terwarnai pada sebagian besar sel tumor.

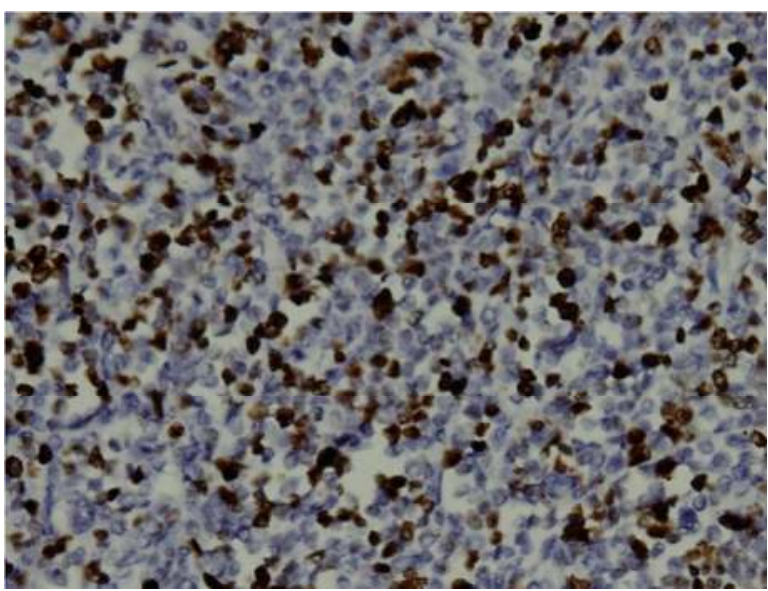

Gambar 4. Pewarnaan imunohistokimia Ki-67. Tampak pulasan positif sedang-kuat pada inti sel tumor (indeks proliferasi 30\%-40\%).

\section{PEMBAHASAN}

Dilaporkan kasus LNH tipe sel kecil pada payudara seorang perempuan usia 50 tahun dan telah dikonfirmasi dengan pemeriksaan imunohistokimia dengan diagnosis akhir mantle cell lymphoma payudara.

Limfoma non Hodgkin merupakan keganasan yang sangat jarang mengenai payudara. Insidennya sekitar 2,2\% dari semua limfoma ekstranodal dan 0,04 hingga $0,5 \%$ keganasan payudara. ${ }^{6} \mathrm{MCL}$ adalah $\mathrm{LNH}$ yang sel neoplastiknya berasal dari diferensiasi sel- $\beta$ dalam zona mantel. ${ }^{7}$

Mantle cell lymphoma (MCL) merupakan neoplasma sel- $\beta$ matur yang terdiri dari sel-sel limfoid kecil-sedang, monomorfik dengan kontur nukleus yang ireguler dan pada > 95\% kasus mengalami translokasi
CCND1. Neoplasma ini terjadi pada usia paruh baya atau individu yang lebih tua dengan usia rata-rata 60 tahun. ${ }^{6,8-10}$

Kasus mantle cell lymphoma pada payudara ini menarik karena merupakan kasus yang sangat jarang. Berdasarkan literatur, kasus mantle cell lymphoma pada payudara pernah dilaporkan oleh Windrum et al pada tahun 2001 yang menemukan kasus MCL pada payudara kanan perempuan berusia 53 tahun. ${ }^{11}$ Argatoff et al (1997) juga melaporkan bahwa dari 80 kasus MCL yang diteliti selama 7 tahun didapatkan satu kasus MCL dengan presentasi pada payudara. ${ }^{12}$

Sesuai dengan kepustakaan, gejala yang muncul pada LNH payudara adalah massa pada payudara yang teraba dengan atau tanpa limfadenopati aksila ipsilateral. ${ }^{13}$ Gejala klinik yang ditemukan pada pasien ini adalah benjolan di payudara kanan sejak 1 tahun terakhir yang semakin bertambah besar. Vural et al juga melaporkan kasus LNH di payudara dengan gejala klinik adanya benjolan di payudara kanan yang bertambah besar dalam 2 bulan terakhir. ${ }^{14}$ Pada laporan kasus Marinopoulos et al menyebutkan gejala klinik yang muncul adalah benjolan di payudara kanan dan di aksila kiri. ${ }^{15}$

Awalnya pasien diduga menderita karsinoma payudara dan dilakukan mastektomi. Berdasarkan literatur disebutkan bahwa presentasi klinis limfoma maligna di payudara baik primer atau sekunder sulit dibedakan dengan neoplasma payudara lainnya. ${ }^{4,14}$ Presentasi limfoma di payudara ini menyebabkan sebagian besar pasien secara klinis dianggap menderita karsinoma payudara. ${ }^{13}$

Pada pemeriksaan histopatologi, mikroskopik tampak stroma mengandung proliferasi sel-sel limfoid berukuran kecil (1-2x ukuran limfosit) monomorf dan tersebar difus diantara stroma. Sel-sel dengan inti pleomorfik, hiperkromatik, berlekuk, membran inti iregular, di antaranya tampak beberapa sel plasma. Berdasarkan gambaran mikroskopik di atas dibuat diagnosis limfoma non Hodgkin tipe sel kecil sugestif mantle cell lymphoma (payudara). Berdasarkan literatur gambaran mikroskopis ini sesuai untuk limfoma non Hodgkin tipe sel kecil sugestif mantle cell lymphoma (payudara) dimana pada pemeriksaan mikroskopik dapat ditemukan proliferasi sel-sel limfoid yang monomorf tumbuh membentuk struktur nodul 
yang samar, difus, zona mantel atau kadang-kadang dengan susunan folikuller. Pada banyak kasus tumor tersusun atas sel-sel limfoid berukuran kecil-sedang dengan membran inti ireguler, ada juga sel-sel yang menyerupai sel sentrosit. ${ }^{6,16}$

Pemeriksaan imunohistokimia diperlukan untuk mengonfirmasi subtipe tumor. ${ }^{17,18}$ Pada kasus ini dianjurkan pemeriksaan imunohistokimia CD 20, Cyclin D1 dan ki-67 untuk mengetahui diagnosis pasti dan prognosis. Dari pemeriksaan imunohistokimia didapatkan CD 20 dan cyclin D1 positif, serta Ki-67 terwarnai $30-40 \%$. Diagnosis pasien disimpulkan mantle cell lymphoma payudara dengan indeks proliferasi tinggi.

Pasien ini memiliki faktor-faktor prognosis yang buruk diantaranya yaitu ukuran tumor yang besar, subtipe limfoma derajat tinggi dengan indeks proliferasi yang tinggi serta varian blastoid. Untuk itu pasien perlu diberikan terapi kemoterapi kombinasi dengan R-CHOP dan R-Bendamustine. ${ }^{19-21}$

\section{DAFTAR KEPUSTAKAAN}

1. Pérez FF, Lavernia $J$, Aguiar-bujanda $D$ Miramón J, Gumá J, Álvarez R, et al. Primary breast lymphoma: Analysis of 55 cases of the Spanish Lymphoma Oncology Group. Clin Lymphoma, Myeloma Leuk. 2017;17(3):186-91.

2. Moura C, Leite MI, Parreira R, Medeiros A. Primary breast lymphoma. Journal of Surgical Case Report. 2020;1:1-3.

3. Hoda SA, Brogi E, Koerner FC, Rosen PP, editor (penyunting). Rosen's breast pathology. Edisi ke-

4. Philadelphia: Lippincott William \& Wilkins; 2014.

4. Aviv A, Tadmor T, Polliack A. Primary diffuse large B-cell lymphoma of the breast: looking at pathogenesis, clinical issues and therapeutic options. Annals of Oncology, 2013;24(5):223644.

5. Liu J, Wei H, Zhu K, Lai L, Han X, Yang Y. Male breast cancer and mantle cell lymphoma in a single patient. Medicine.2017;96(48):1-4

6. Swerdlow SH, Campo E, Harris NL, Jaffe ES, Pileri SA, Stein $\mathrm{H}$, et al. editor (penyunting). WHO classification of tumour of haematopoietic and lymphoid tissues. Edisi ke-4. Lyon:
International Agency for Research on Cancer (IARC); 2017

7. Weiss L, editor (penyunting). Lymph nodes. New York: Cambridge university press; 2008.

8. Ondrejka SL, Lai R, Smith SD, Hsi ED. Original articles indolent mantle cell leukemia: a clinicopathological variant characterized by isolated lymphocytosis, interstitial bone marrow involvement, kappa light chain restriction, and good prognosis. Haematologica. 2011; 96 (8): $1121-7$.

9. Iqbal M, Castano YG, Sher T, Kharfan-dabaja MA. Intraocular involvement of mantle cell lymphoma: A case report and literature review. Hematol Oncol Stem Cell Ther. 2019; 03 (002): $1-6$.

10. Report AC. Primary cutaneous mantle-cell Lymphoma. Journal of Clinical Oncology. 2019;33(26):104-8.

11. Windrum P, Morris TCM, Catherwood MA, Alexander HD, Mcmanus DT. Mantle cell lymphoma presenting as a breast mass. J Clin Pathol. 2001;54:883-6.

12. Argatoff LH, Connors JM, Klasa RJ, Horsman DE, Gascoyne RD. Mantle cell lymphoma: A Clinicopathologic study of 80 cases. Blood journal. 1997;89(6):2067-78.

13. Gupta V, Bhutani N, Singh S, Chhabra S, Sen R. Human pathology: Case Reports primary nonHodgkin ' s lymphoma of breast - A rare cause of breast lump. Hum Pathol Case Reports. 2017; $7: 47-50$

14. Vural F, Saydam G, Sahin F, Soyer NA, Hekimgil M. Non-Hodgkin's lymphoma of the breast: Report of five cases and review of the literature. International Journal of Hematology and Oncology. 2012;22(3):195-201.

15. Marinopoulos S, Safioleas P, Skorda L, Vassilopoulou E, Zagouri F, Sotiropoulou M, et al. Breast lymphoma in a patient with B-cell Non Hodgkin Lymphoma: A case report study. International Journal of Surgery Case Reports. 2017;40:1-5.

16. Kiel MJ, Smith LB. Transformation of indolent mantle cell lymphoma to pleomorphic mantle cell lymphoma case report and review of clinical and 
morphologic variants. Arch Pathol Lab Med. 2012;136:871-5.

17. Evens $\mathrm{AM}$, Blum KA, editor (penyunting). Non Hodgkin lymphoma, pathology, imaging, and current therapy. Switzerland: Springer International Publishing; 2015.

18. Nizam I, Erkurt MA, Berber I, Kaya E, Kuku I, Koroglu M. Aggressive progression of mantle cell lymphoma. American Journal of Medical Case Reports. 2014;2(1):30-1.

19. $\mathrm{Pu} \mathrm{JJ}$, Chepovetsky J, Cristina I. A rare case of synchronous breast carcinoma and mantle cell lymphoma : Successful treatment of both cancers with Bendamustine / Rituxan combination. Austin J Clin Case Report. 2014;1(12):1-3.

20. Jain P, Wang M. Mantle cell lymphoma: 2019 update on the diagnosis, pathogenesis, prognostication, and management. Am J Hematol. 2019;94:710-25.

21. Dreyling $M$, Amador $V$, Callanan $M$, Jerkeman $M$, Gouill S Le, Pott C, et al. Update on the molecular pathogenesis and targeted approaches of mantle cell lymphoma: summary of the 12th annual conference of the European Mantle Cell Lymphoma Network. J Leukemia \& Lymphoma. 2014; Early Online: 1-11. 